\title{
PLANNING FOR GYPSUM GEOHAZARDS IN LITHUANIA AND ENGLAND
}

\author{
Bernardas Paukštys, GROTA Hydrogeological Company, Eisiskiu pl 26, LT-2038 Vilnius, Lithuania \\ Anthony H.Cooper, British Geological Survey, Keyworth, Nottingham, NG12 5GG UK. \\ Jurga Arustiene, Geological Survey of Lithuania, S.Konarskio 35, LT-2600 Vilnius, Lithuania
}

Published in Engineering Geology Vol 52 (1999) 93-103.

This manuscript differs slightly from the published paper and lacks heading numbers etc.

The published paper should be considered as the definitive version

DOI: 10.1016/S0013-7952(98)00061-1

http://www.sciencedirect.com/science/article/pii/S0013795298000611

Keywords: Gypsum karst; Subsidence; Hazard; Planning; Karst hydrogeology

\begin{abstract}
The rapid underground dissolution of gypsum, and the evolution of the gypsum karst in Lithuania and England, results in subsidence problems which can make construction difficult. The natural dissolution yields sulphate-rich groundwater of poor quality and the karst is susceptible to the rapid transmission of pollutants.

In the north of Lithuania gypsum karst is developed in Devonian gypsum. Here the towns of Biržai, Pasvalys and the surrounding countryside suffer subsidence and some buildings have been damaged. The majority of the potable water in these areas is derived from groundwater abstracted from sandstone sequences that underlie the gypsum. In Lithuania conservation measures have been introduced to control agriculture and prevent pollution of the gypsum karst. These measures include environmentally-friendly farming, restrictions on land use and exclusion zones around subsidence hollows.

In England subsidence caused by the dissolution of Permian gypsum has caused severe problems in the vicinity of the town of Ripon. Numerous buildings have been damaged and new sites are difficult to develop. Here formal planning regulations have recently been introduced to help to mitigate against the worst effects of subsidence resulting from gypsum dissolution.
\end{abstract}

\section{INTRODUCTION}

Gypsum is a very soluble mineral which can dissolve at a rapid rate. Where natural dissolution of exposures has occurred adjacent to rivers it is common for one metre of gypsum to be dissolved away in a year or so (James et al, 1981; James, 1992). Where this dissolution has occurred or is occurring, underground cave systems can develop such as those explored in the Ukraine (Andrajchouk and Klimchouck, 1992), Germany (Biese, 1931; Pfeiffer and Hahn, 1972) and Spain (Pulido-Bosch and Calaforra, 1993). Because the dissolution rate is so rapid gypsum cave systems can enlarge at a considerable rate, ultimately become unstable, and collapse causing subsidence problems at the surface. The mechanism of collapse causes sub-vertical breccia pipes to develop with subsidence hollows where these break through to the surface (Cooper, 1986, 1988, 1995).

In most countries where gypsum occurs in contact with water there are associated subsidence problems. In farmland these are inconvenient, but in urban areas they constitute a geological hazard that can seriously affect development and human safety. Gypsum geohazards affect the towns of Biržai and Pasvalys in Lithuania (Paukštys, 1996), Ripon and Darlington in England (Cooper 1995 and references therein). Elsewhere in Europe gypsum geohazards are present in many towns and cities. For example, in Spain they have been recorded in the city of Zaragoza (Benito et al., 1995) and the town of Calatayud (Gutiérrez, 1996); in France they affect the outskirts of Paris (Toulemont, 1984) and in Germany Stuttgart and many towns peripheral to the Hartz Mountains suffer subsidence (Pfeiffer and Hahn, 1972; Ströbel, 1973). In addition to these examples, gypsum dissolution and subsidence affects many more urban and rural areas in these and many more countries. Some of these areas may be the sites of future roads, reservoirs or urban growth. Thus, an appreciation of gypsum geohazards is important for planning and development on a national, provincial and local scale.

In addition to the problems of subsidence, some countries such as Lithuania rely heavily on groundwater for their potable water supplies (Klimas and Paukštys, 1993; Paukštys, 1996). Despite its mineral content sulphate-rich water, associated with the gypsum karst areas, is sometimes the only water supply that can be obtained. Abstraction of this water, or water from aquifers in continuity with the gypsum karst, can result in subsidence both by drawdown of the water table and by increasing the dissolution of gypsum especially in the vicinities of boreholes. Drawdown of the water table causes a loss of hydrostatic buoyancy, the effective weight of cavity fill increases and collapse can occur. Drawdown can also wash material deeper into cavities and aggravate the subsidence problems. Another problem is that the rapid passage of groundwater, both through limestone and gypsum karst, can lead to the swift transmission of pollutants from their 
source to a potable water supply (Klimas and Paukštys, 1993). Gypsum karst, therefore, demands careful management and possible protection if the land and water associated with it are to be used to their full potential.

\section{GEOLOGY, SUBSIDENCE AND HYDROLOGICAL CONSIDERATIONS IN THE GYPSUM KARST OF LITHUANIA Geology}

The karst area of northern Lithuania covers about 20,000 sq km, of which about $1000 \mathrm{sq} \mathrm{km}$ are composed of gypsum karst. The gypsum karst area is well developed around the towns of Pasvalys and Biržai extending northwards into Latvia (Figure 1).

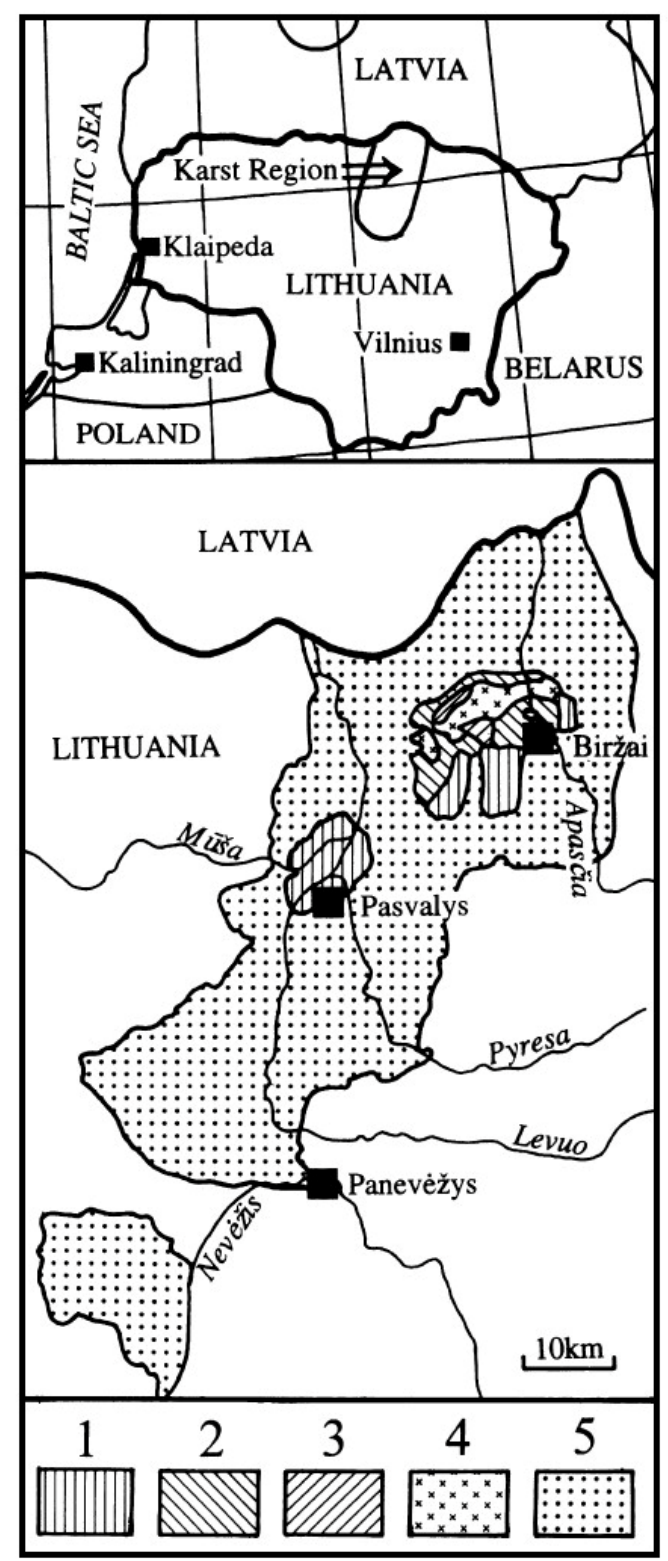

Figure 1. The location of the gypsum karst area in northern Lithuania and the agricultural protection zonation. 1. Land Group 1, less than 20 sinkholes/100ha; 2. Land Group 2, 20-50 sinkholes/100ha; 3. Land Group 3, 50-80 sinkholes/100ha; 4. Land Group 4, more than 80 sinkholes/100ha; 5. Karst protection zone; (100ha equals $1 \mathrm{sq} \mathrm{km}$

The gypsum in northern Lithuania is of late Devonian age. It occurs in the Tatula Formation where two main gypsiferous sequences are present, interbedded with dolomites and marls (Table 1); gypsum comprises about 70 percent of the sequence. The gypsum sequence is underlain by dolomites of the Pliavinias Formation including the thin Jara aquiclude which overlies the sandstone aquifer of the Šventoji Formation and the argillaceous sandstones aquifer of the Upninkai Formation. Below this the Narva Clay Formation forms a regional aquiclude that limits the karstic aquifer basin. The gypsum karst is locally covered by the thin (3-9m) dolomite of the Ystra Formation, but over most of the outcrop it is concealed by Quaternary deposits which are up to about $20 \mathrm{~m}$ in thickness. The Quaternary deposits are glacial tills with lenticular belts of sand which form minor local near-surface aquifers. 


\section{Subsidence}

The gypsum karst area of northern Lithuania has well-developed sinkholes that range in density from 20 to 200 per 100 ha (per square kilometre). They range in size from a few metres to $60 \mathrm{~m}$ in diameter and are up to $12 \mathrm{~m}$ in depth (Marcinkevičius and Bucevičiute, 1986). The sinkholes are concentrated in areas related to the valleys and water divides of the Muša, Levuo and Pyvesa rivers with the greatest density of sinkholes on the Kirkilai geological reserve. Here, in the bottom of one sinkhole, there is also a small accessible cave in the gypsum. This cave, dedicated as a geological monument, is up to $3.1 \mathrm{~m}$ high, with $46 \mathrm{~m}$ of accessible passages; it is of phreatic origin with water-eroded scallops on the roof, but it is now only half full of water (Laiconas, 1979). Elsewhere in this area, stream sinks of moderate size, such as the sinking of the $8 \mathrm{~km}$ long Požemis stream, indicate more extensive cave development. Prolific springs, common in the gypsum karst area, also suggest cave development. Major karst springs occur along the Levuo River at Pasvalys town, the Orija river near Berklainiai Village and the Apašèia river near Draseikiai Village.

The majority of the sinkholes (61 percent) are oval in shape and their long axes relate to the main joint directions in the gypsum which are to the northeast, north and east (Marcinkevičius and Bucevičiute, 1986; Bucevičiute and Marcinkevičius, 1992). Lines of hollows also appear to relate to these joint directions. In the area of active karst more than 8500 sinkholes are present in an area of $400 \mathrm{sq}$. km (Bucevičiute and Marcinkevičius, 1992). By comparison with gypsum karst elsewhere it may be expected that many of the subsidence features are underlain by breccia pipes that extend to the base of the gypsum. This is suggested by boreholes in the gypsum karst, which penetrate cavities, foundered strata and washed in materials within the gypsum. The deepest breccia pipe so far found, in the Radviliškis region, extended to $96.4 \mathrm{~m}$ in depth (Bucevičiute and Marcinkevičius, 1992)

Active gypsum dissolution is indicated by the high concentrations of sulphates in groundwater coming from the various karst springs and also in the surface water of the main drainage courses such as the River Tatula. Active gypsum dissolution is also shown by the continuing collapse of the gypsum karst and the development of sinkholes, though their development may be aggravated by water abstraction and changes in the water table levels. Where this collapse has occurred in urban areas, damage has ensued in both Pasvalys and Biržai.

\section{Hydrogeological considerations}

In the gypsum karst area of northern Lithuania the main water supply comes from the Devonian aquifers. They are exploited through about 600 bored wells with individual yields of between 10 and $50 \mathrm{~m}^{3} /$ day. In addition to the scattered wells, boreholes at the waterworks of Biržai and Pasvalys abstract 2000 and $2600 \mathrm{~m}^{3} /$ day from the aquifers. These large-scale abstractions have caused a drawdown in the water table of $7.5 \mathrm{~m}$ since 1970 at Pasvalys, and 8m since 1961 at Biržai. The karst area is currently monitored by GROTA, under the auspices of the Tatula Board (set up by Government decree), at 50 drilled wells, dug wells and karst springs. The detailed results of long-term monitoring and complex mathematical modelling of the karst aquifers are presented by Paukštys (1996). In addition to the effects of local water abstraction, up to $110,000 \mathrm{~m} 3 /$ day is forecast to be taken by the large town of Panevezys, 40-60km south of the gypsum karst area. This amount of abstraction could have serious future drawdown effects on the gypsum karst water. Because drawdown is likely to aggravate the subsidence problems, future water abstraction from the near-surface gypsum-dolomite karst aquifers has already been prohibited, but this remote abstraction could be dangerous. In addition to subsidence caused by drawdown, the lowering of the water table allows more aggressive groundwater to enter the gypsum karst. Approximate calculations carried out using the Lithuanian data show that the lowering of groundwater by 1 metre increases the gypsum deficiency by $0.4 \mathrm{~g} / 1$ (Paukštys, 1996). In addition to the degradation of potable water, laboratory experiments and detailed chemical modelling show that common fertilizer compounds within the gypsum karst water can lead to enhanced gypsum dissolution (Paukštys, 1996). The preferred aquifer for large-scale water abstraction is the Šventoji and Upninkai formations. These contain the best quality water, but with continued abstraction are themselves becoming slightly contaminated with water drawn down from the overlying aquifers.

In order to categorise the susceptibility of the gypsum karst to pollution, classification and analysis was applied to 19 variables; this is the grade method of Dublianskij et al. (1990). It involved defining the controlling parameters of the karst system. Solubility was defined by four factors: lithology, thickness of gypsum deposits, content of soluble material and geological structure. Permeability was defined by five factors: lithology of overlying sediments, thickness of overlying sediments, density of sinkholes, dip of the karst rocks and coefficient of transmissivity. The availability of groundwater was characterised by six factors: amount of effective precipitation, surface runoff, subsurface runoff, downward infiltration, seepage from neighbouring aquifers and groundwater gradient. The aggressivity of the groundwater was characterised by three factors: water saturation degree as TDS, temperature and $\mathrm{pH}$. In addition to these factors, the number of old karst features (breccia pipes and debris-filled areas) were also considered. Using this technique, an integral grade scale was determined by summing up the separate active factors of the karst terrain. This allowed the karst to be divided into areas of weak karst (3242 grades); medium karst (43-49 grades) and high karst (50-59) grades. These grades relate closely to the classification (Figure 1) of the karst lands used for agricultural protection (Paukštys, 1996). 


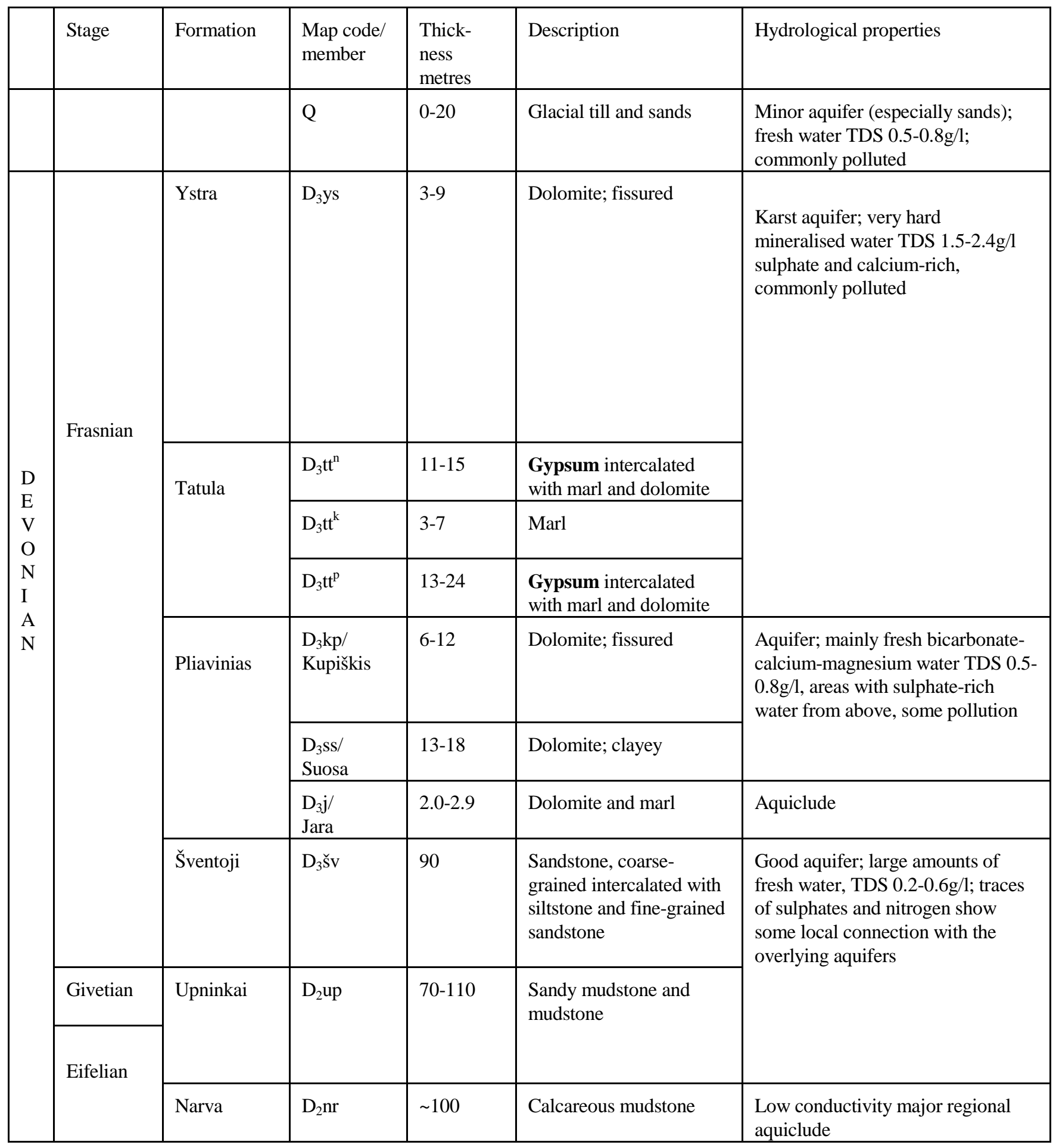

Table 1. The sequence of Devonian rocks in the north of Lithuania and their main lithological and hydrological properties. 


\section{GEOLOGY, SUBSIDENCE AND HYDROLOGICAL CONSIDERATIONS IN THE GYPSUM KARST OF ENGLAND \\ Geology}

In England gypsum karst and subsidence problems are mainly developed in the Permian sequence in northeast England (Figure 2).Gypsum is present in the Edlington and Roxby formations from just north of Doncaster, through Ripon to Darlington and Hartlepool. Up to 40m of gypsum are present in the Edlington Formation and 10m in the Roxby Formation (Table 2). Both these gypsum sequences rest on dolomite aquifers and are capped by a marl sequence. However, in the subsidence-prone areas the amount of dissolution and collapse is so great that the marls are perforated by subsidence pipes and form very ineffective aquicludes. The Permian sequence is capped by the Triassic Sherwood Sandstone Group a major regional aquifer. In addition to the Permian gypsum the majority of the English mined gypsum is in the Triassic Mercia Mudstone Group (Figure 2). Some subsidence has been noted associated with this gypsum, but since the gypsum is sandwiched in mudstone aquicludes, subsidence is much more restricted in area. However, the dissolution of gypsum from the near-surface mudstones has considerably disrupted the fabric of the upper part of the mudstone sequence. This disruption and associated weathering have commonly resulted in the deposits presenting difficult ground for civil engineering purposes.

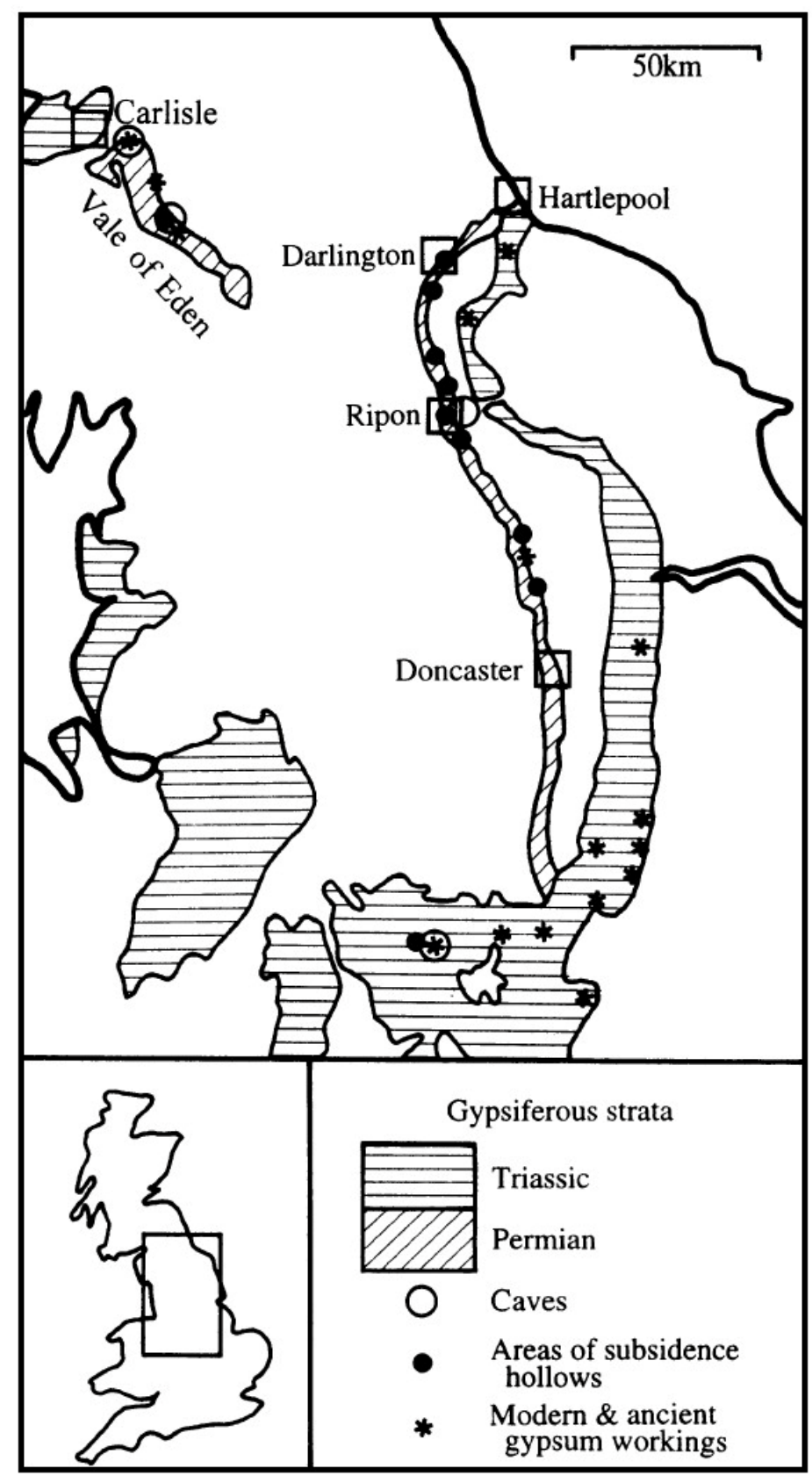

Figure 2. The distribution of the main gypsiferous strata in England showing the location of past and present mines (asterisks), caves (open circles) and subsidence hollow areas (solid dots). 


\section{Subsidence}

The two gypsum sequences of the Edlington and Roxby formations rest on the limestone aquifers of the Cadeby and Brotherton formations respectively. The limestone dip slopes act as catchment areas and the water is fed down-dip into the gypsiferous sequences, before escaping into a major buried valley along the line of the River Ure (Cooper \& Burgess, 1993). Complex cave systems are developed in the gypsum and artesian sulphate-rich springs are locally present. Because of the thickness of gypsum present the caves are large and surface collapses up to $30 \mathrm{~m}$ across and $20 \mathrm{~m}$ deep have been recorded. The subsidence is not random, but occurs in a reticulate pattern related to the jointing in the underlying strata (Cooper, 1986, 1989). Around Ripon a significant subsidence occurs approximately every year (Cooper, 1995). The times of the subsidence events show that some zones of subsidence are more active than others. Furthermore, areas bounding the Ure valley are more subsidence-prone due to the localised escape of cave water into the buried valley gravels. In England, gypsum caves and subsidence are not confined to Ripon; the subsidence-prone belt is about 3-4km wide and extends from near Doncaster to Hartlepool. Several areas along this belt suffer gypsum-related subsidence, though none are as severe as Ripon. Subsidence also affects the Darlington area, but in the urban district of this town the problems are lessened by the presence of thick Quaternary glaciogeneic deposits (Cooper, 1995).

\section{Hydrogeological considerations}

The natural dissolution of gypsum results in large quantities of sulphate in the groundwater. Consequently, in and around Ripon, many springs, and waters in the glacial deposits are high $(0.8-2.0 \mathrm{~g} / \mathrm{l})$ in sulphate. Calculations suggest that the volume of gypsum being dissolved naturally each year at Ripon is about $120 \mathrm{~m}^{3} / \mathrm{sq} \mathrm{km}$. However, north of Ripon a figure of around $1000 \mathrm{~m}^{3} / \mathrm{sq} \mathrm{km}$ may have been removed since the last (Devensian) ice age. In addition to this natural dissolution, abstraction of groundwater high in sulphates can remove considerable volumes of gypsum from underground. It is estimated (Cooper, 1988) that the volume of gypsum removed by a group of boreholes in a subsidence damaged area of Ripon abstracting $212 \mathrm{Ml}$ of water a year, was approximately $200 \mathrm{~m}^{3}$ per annum. It is likely that much of the dissolution represented enlargement of joints over a considerable area. However, in the vicinity of the boreholes, where rapid groundwater flow occurs, severe dissolution of the gypsum beds could have occurred.

In addition to the dissolution problems the resedimentation of Quaternary deposits into the gypsum karst may have resulted in surface subsidence in the former. This could also have been enhanced by localised lowering of the water table. Similar problems of glacial deposits being displaced into gypsum karst, and causing subsidence, have been suggested as a mechanism for the development of subsidence in the Darlington area (Cooper, 1995).

\begin{tabular}{|l|l|l|l|l|}
\hline & Formation/Group & $\begin{array}{l}\text { Thickness } \\
\text { metres }\end{array}$ & Description & Hydrological Properties \\
\hline $\begin{array}{l}\text { TRI- } \\
\text { ASSIC }\end{array}$ & Sherwood Sandstone Group & 300 & $\begin{array}{l}\text { Red sandstone with subordinate } \\
\text { mudstone beds, especially near } \\
\text { base }\end{array}$ & $\begin{array}{l}\text { Major regional aquifer } \\
\text { TDS 0.15-0.3g/l mainly as CaCO }\end{array}$ \\
\hline \multirow{2}{*}{$\begin{array}{l}\text { E } \\
\text { R } \\
\text { M } \\
\text { I } \\
\text { A }\end{array}$} & Roxby Formation & up to 26 & $\begin{array}{l}\text { Red-brown calcareous } \\
\text { mudstone (marl) with up to } \\
\mathbf{1 0 m} \text { of gypsum at base }\end{array}$ & $\begin{array}{l}\text { Very leaky aquiclude with a gypsum } \\
\text { karst aquifer at base; sulphate-rich } \\
\text { water }\end{array}$ \\
\cline { 2 - 5 } & Brotherton Formation & $8-14$ & $\begin{array}{l}\text { Calcitic dolomite, mainly in } \\
\text { thin beds }\end{array}$ & $\begin{array}{l}\text { Aquifer TDS 0.5g/l as CaCO } \\
\text { sulphate-rich in places }\end{array}$ \\
\cline { 2 - 5 } & Edlington Formation & up to 50 & $\begin{array}{l}\text { Red-brown calcareous } \\
\text { mudstone (marl) with up to 30- } \\
\mathbf{4 0 m} \text { of gypsum at base }\end{array}$ & $\begin{array}{l}\text { Very leaky aquiclude with a gypsum } \\
\text { karst aquifer at base TDS } 0.8-2.0 \mathrm{~g} / 1 \\
\text { mainly as sulphate }\end{array}$ \\
\hline
\end{tabular}

Table 2. The sequence of the Permian and Triassic rocks in northeastern England and their main lithological and hydrological properties.

\section{PLANNING IN, AND MANAGEMENT OF, GYPSUM KARST AREAS}

Hazard avoidance, the most cost-effective form of planning

The use of special building and development techniques, such as those outlined below, are expensive. If funding is not available, remediation or control schemes cannot be implemented and it is impossible to legislate for special construction regulations. However, planning to avoid the worst of the hazardous areas, and to limit the aggravation of the subsidence problems, can be very cost-effective. The winners are people who avoid paying for constructions that subsequently fail, the losers are those with land that becomes less valuable for development. Avoidance of the worst areas causes less planning blight than developing and suffering severe subsidence and destruction of property and infrastructure. 
It is largely impossible to avoid all development within the gypsum karst areas. In towns such as Ripon, where the margin of the subsidence belt runs through the town it may be possible to encourage more development outside of the subsidence belt. However, within the subsidence areas the first principle of avoiding gypsum geohazards is generally not to build in existing subsidence hollows. This is because they may still be unstable, they may have ongoing dissolution below them, or they may be filled with poorly consolidated deposits (or waste materials) with a low bearing strength. The second principle is not to build on the margins of the existing hollows, or between hollows in linear belts. This is because the collapse of a hollow can lead to the choking of the underlying cave system. When this happens, the dissolution area can be pushed to the margins of the collapse and affect the adjacent ground. In this way subsidence hollows commonly occur in lines or close groupings. The third principle is to avoid the most active areas where the majority of the recent subsidence hollows have occurred.

\section{Development and construction of buildings}

The construction of buildings within gypsum karst requires special measures. In England the Government's Department of the Environment and Harrogate Borough Council (the local council to the Ripon area) have recently commissioned a report on planning and development in the subsidence-prone area (Thomson et al., 1996). The report approaches the problems on two fronts, construction and planning. For construction it reviews the problem and gives some possibilities for the types of foundations suitable for use in subsidenceprone areas. Options include raft foundations, jackable foundations and reinforced strip foundations. The report reiterates the difficulties and dangers of piling into gypsum karst, or of trying to improve the ground by grouting, these factors were discussed by Cooper (1995). Another approach to development is the use of extended foundations such as those suggested by Sorochan et al. (1985), or the construction of properties on linked foundations to prevent individual houses collapsing into subsidence hollows. In addition to these measures, precautions to protect services such as gas, water, electricity and sewerage, are also desirable. These precautions could include flexible pipe work, flexible connections and protection such as geogrid materials or reinforced supports.

The second approach to the subsidence problem recommended by Thomson et al. (1996) is through the planning regulatory process. To support this process the Ripon area has been divided into three development control zones: (A) no know gypsum present; (B) some gypsum present at depth; (C) gypsum present and susceptible to dissolution. Within zone A no special planning constraints would be imposed. In zone B, where the risk of subsidence is small, a ground stability report prepared by a competent person would usually be required and the problem should be considered in local planning. The zone $\mathrm{C}$ area would be potentially subject to significant constraints on development and local planning should take these into account. Also within this zone, development is subject to controls. A ground stability report prepared by a competent professional person would normally be required before planning applications for new buildings, or change of use of buildings, are determined. In most cases this report would need to be based on a geotechnical desk study and a site appraisal, followed by a programme of ground investigation designed to provide information needed for detailed foundation design (unless this information, such as boreholes, exists from a previous study). Where planning consent is given it may be conditional on the implementation of approved foundation or other mitigation measures, designed to minimise the impact of any future subsidence activity. One key to the implementation of this approach is the use of a proforma checklist to be completed and signed by a competent professional person. For the UK a competent person is defined in the report as Geotechnical Specialist who is "A Chartered Engineer or Chartered Geologist, with a postgraduate qualification in geotechnical engineering or engineering geology, equivalent at least to an MSc, and with three years of post-Charter practice in geotechnics; or a Chartered Engineer or Chartered Geologist with five years of post-Charter practice in geotechnics". In addition to these qualifications it is also desirable that the practitioner has experience of the problems though this is not formally stated. This procedure has been adopted by Harrogate Borough Council, but is likely to be subject to minor changes with experience of its use.

\section{Development and construction of roads and bridges}

Sudden failure of roads over natural and manmade cavities have led to collapses in which vehicles have fallen into the resultant cavity. It is largely impractical to engineer roads with design parameters of sufficient strength to span the larger subsidence features. Even if this could be done the removal of support from beneath such structures could ultimately result in subsidence features migrating, and the structures themselves failing catastrophically in a much larger way than non-protected structures. One practical approach that was adopted for a new bypass at Ripon was to incorporate several layers of geogrid material into the embankments of the road. If a subsidence develops beneath the road, the area of the subsidence will sink, but should not fail catastrophically. When subsidence occurs its location will be obvious and some remedial measures can be undertaken. The use of geogrid materials is also a satisfactory method of protecting car parks and public spaces.

The development of bridges in such situations is difficult. At Ripon the new road bridge has been built on the principle of having sacrificial supports. The deck of the bridge has been strengthened, and built as a continuous structure, so that the loss of support of any one upright will not cause it to collapse. A system of monitoring the loads on each support has been built into the bridge, and a warning system installed to warn of any pier failure. In addition to these measures, extending the foundations of each pier laterally to an amount which could span the normal-sized collapses would give an added degree of security.

\section{Water abstraction}

Some details of the dangers of water drawdown and the active dissolution of gypsum are given above and in Cooper (1988) and Paukštys (1996). Because it is possible to enhance both the local dissolution and cause of subsidence by the drawdown of the water table 
levels, careful monitoring and regulation of water abstraction is essential in gypsum karst areas. In England and Lithuania attention is genrally paid to water quality, but not so much thought is given to the subsidence implications of water abstraction.

Another factor that must be considered is the effect of pollution on gypsum karst. Because the gypsum karst has rapid transmissivity, in fissures and caves, it is important to consider the implications of agriculture and waste disposal on water quality. If the water is used only for irrigation a moderate content of nitrate and phosphate may not be immediately problematical. If the water is to be used as a potable supply then rapid fluctuations in contaminants may occur. In such areas, careful consideration should also be given to protecting the gypsum karst from accidental contamination by spillage of chemicals, poor containment of farm wastes and foul water disposal.

\section{Karst water protection and agriculture}

In the Lithuanian karst area, 27,600 hectares (276 sq km) of intensive karst, with strict agricultural limitations, and 166,000 hectares $(1,660 \mathrm{sq} \mathrm{km})$ of karst protection zone have been designated by government decree. Within this area (Figure 1), four divisions of agricultural land use have been defined based mainly on the number of sinkholes per square kilometre. The categories and restrictions imposed are:

Land group 1 (up to 20 sinkholes/100 ha). Grain crops should compose at least $50 \%$ of arable lands, perennial grass $40 \%$ and root crops (potatoes and sugar beet) not more than $10 \%$. Fertilisers are limited to a maximum of $90 \mathrm{~kg} / \mathrm{ha}$ of nitrogen/phosphorus/potassium (NPPt active ingredients) and 80 t/ha of manure. Triazinic herbicides and Chloroganic insecticides are prohibited.

Land group 2 (20-50 sinkholes/100 ha). Grain crops should compose $43 \%$ or arable lands and perennial grass $57 \%$. Root crops (potatoes and sugar beet) are prohibited as is the setting up of new orchards and gardens. Fertilisers are limited to a maximum of $60 \mathrm{~kg} / \mathrm{ha}$ of NPPt and $60 \mathrm{t} / \mathrm{ha}$ of manure.

Land group 3 (50 - 80 sinkholes/100 ha). Perennial grass and pastures only are allowed. Fertilisers are limited to a maximum of $60 \mathrm{~kg} / \mathrm{ha}$ NPK. Mineral nitrogen fertilisers are prohibited as are pesticides (except for fungicides).

Land group 4 (80 - 100 sinkholes/100 ha). Only meadows and forests are allowed. All fertilisers and pesticides are prohibited. In all the land groups a $25 \mathrm{~m}$ radius protection zone is required around each doline. Within this protection zone only grass without fertilisers or pesticides may be grown.

In addition to these measures it is illegal to apply ammonium water and liquid ammonium to the soils of all four categories. It is also prohibited to use aircraft for spraying chemicals and mineral fertilizers. Ecologically sound agricultural plans have been designed for each land group. Biological agriculture is being introduced to the region. Thus, the protection of karst water from pollution and the reduction of human impacts on vulnerable karst groundwater is now official government policy. Funding from the national budget, therefore, is being provided to enable the implementation of the necessary protection measures (building of waste water treatment plants, manure storage facilities etc.). It is hoped that the introduction of these protection measures will stabilise karst development in the karst region of Lithuania.

The Tatula Board, named after the karst River Tatula, is officially responsible for the protection of the gypsum karst area and its important groundwater resources. It was established to comply with Resolution 589 of the Government of Lithuania, December 24th 1991. This resolution officially recognised the karst area and formalised protection and monitoring procedures in the area. The programme of measures was adopted by the Decree of the Lithuanian Government by Resolution 719 on September 17th 1993. The Tatula Board is funded through the Ministry of Agriculture from central government funds. It encourages environmentally-friendly agriculture and antipollution measures in the gypsum karst area. It does this by organising training courses at the local college, publishing advisory brochures and encouraging organic farming. It also tries to help the funding of water treatment plants for treating effluent. To limit the amounts of nitrate, phosphate and potassium entering the karst water, the Tatula Board helps farmers with interest-free loans for developing environmentally-friendly (organic) agriculture. The farmers have to produce a 5-year business plan and agree not to use insecticides and fertilizers. There are currently 43 farms working to sustainable bio/organic agriculture. These farms are all in the 3 rd and 4th karst land groups with 50-80, or more than 80, sinkholes per 100ha (per square kilometre). In all four agricultural categories, around each sinkhole the law is that they must have a $25 \mathrm{~m}$ zone of exclusion to agriculture and around some an earth barrier to prevent runoff entering the hole. The organic farming is monitored by the society for bio-organic agriculture (GAJA), which checks to see that no fertilizers are used. The Tatula Board has a programme which uses 11 institutes and organisations to monitor environmental aspects, such as groundwater. They would like a more extensive remit to include waste water inspection and pollution control.

In contrast, to the protection of the karst water in Lithuania, some unsuitable practices have been noted in England. These include the piping of surface water run off from roads into sinkholes to drain it away. In addition, during the 1970s, some large sinkholes were filled with domestic refuse. Any leachate from this will have drained directly into the gypsum karst water system and may threaten local springs and wells supplying farms.

\section{CONCLUSIONS}

The presence of gypsum constitutes a geological hazard that can be mitigated by careful planning. This planning can be undertaken on several fronts and at several different scales. From a national point of view the starting point is the recognition of the gypsiferous areas as special and potentially dangerous. At the local scale the hazards are best considered as part of locally applied planning and development process. Local development plans should consider the implications of unstable land associated with gypsum karst and avoid the most unstable areas within, and adjacent to, sinkholes; this is the most cost-effective way of mitigating the hazard. Also on a local to regional scale the interaction of groundwater drawdown and recharge within the gypsum karst area needs to be considered. Since water abstraction can trigger the subsidence, it should be carefully controlled. 
Once the development areas have been defined, the hazard can be further mitigated by careful control of building and construction designs. The use of special reinforced and extended foundations can be specified, along with protection to cables and pipes servicing the constructions. The implementation of these measures can be made effective by having local authority control and verification of the investigation and design procedures adopted in the subsidence-prone areas.

Where the gypsum karst is also closely related to the local potable groundwater supply, measures to protect the aquifer can be very beneficial. These measures can include limits on the types of agriculture, and education or regulation to prevent pollution of the groundwater, especially through runoff or illegal drainage into sinkholes.

\section{ACKNOWLEDGEMENTS}

This study has been funded and facilitated by the British Overseas Development Administration (ODA), of the British Foreign Office, under Technical Development and Research (TDR) contract R6490 - Gypsum Geohazards: their impact on development. AHC particularly wishes to thank Drs G.Motuza, J.Satkunas and K.Kadunas plus all the staff at the Geological Survey of Lithuania for their help and hospitality; he wishes to give special thanks to Dr V.Marcinkevi_ius for explaining about the gypsum karst in Lithuania. Drs A.J.Reedman and J.D.Bennett are thanked for helping to arrange this project. T.J.Charsley and Dr J.H.Powell are thanked for reviewing the manuscript. AHC publishes with permission of the Director, British Geological Survey (N.E.R.C.).

\section{REFERENCES}

Andrajchouk, V. and Klimchouk, A. 1993. Environmental change and human impact on karst in Western Ukraine. Catena Supplement. $25,146-160$

Benito, G., Pérez del Campo, P., Gutiérrez-Elorza, M. and Sancho, C. 1995. Natural and human-induced sinkholes in gypsum terrain and associated environmental problems in NE Spain. Environmental Geology, Vol. 25, 156-164.

Biese, W. 1931. Über Höhlenbildung, 1. Entstehung der Gipshölen am südlichen Harzrad und am Kyffhäuser. Abhandlung Preußischen Geologischen Landsanstalt, Vol. 71. 5-69 and 12 plates.

Bucevičiute, S. and Marcinkevičius, V. 1992. Karst morphology. Proceedings of the Lithuanian Higher Schools. Geologija. Vol. 13. 4958. [in Lithuanian].

Cooper, A.H. 1986. Foundered strata and subsidence resulting from the dissolution of Permian gypsum in the Ripon and Bedale areas, North Yorkshire. 127-139 in Harwood, G M and Smith, D B (Editors). The English Zechstein and related topics. Geological Society of London, Special Publication. No. 22.

Cooper, A.H. 1988. Subsidence resulting from the dissolution of Permian gypsum in the Ripon area; its relevance to mining and water abstraction. 387-390 in Bell, F G, Culshaw, M G, Cripps, J C and Lovell, M A (Editors) Engineering Geology of Underground Movements. Geological Society of London, Engineering Geology Special Publication No.5.

Cooper, A.H. 1989. Airborne multispectral scanning of subsidence caused by Permian gypsum dissolution at Ripon, North Yorkshire. Quarterly Journal of Engineering Geology (London), Vol. 22, 219-229.

Cooper, A.H. and Burgess, I.C. 1993. Geology of the country around Harrogate. Memoir of the British Geological Survey, Sheet 62 (England and Wales).

Cooper, A.H. 1995. Subsidence hazards due to the dissolution of Permian gypsum in England: investigation and remediation. 23-29 in Beck, F.B. (Editor.) Karst Geohazards: engineering and environmental problems in karst terrane. Proceedings of the fifth multidisciplinary conference on sinkholes and the engineering and environmental impacts of karst Gatlinburg/Tennessee/2-5 April 1995. 581pp. A.A.Balkema, Rotterdam.

Gutiérrez, F. 1996. Gypsum karstification induced subsidence: effects on alluvial systems and derived geohazards (Calatayud Graben, Iberian Range, Spain). Geomorphology. Vol. 16, 277-293.

James, A.N., 1992. Soluble materials in civil engineering. Ellis Horwood Ltd, England. 433 pp.

James, A.N., Cooper, A.H. and Holliday, D.W. 1981. Solution of the gypsum cliff (Permian Middle Marl) by the River Ure at Ripon Parks, North Yorkshire. Proceedings of the Yorkshire Geological Society, Vol. 43, 433-450.

Klimas, A. and Paukštys, B. 1993. Nitrate contamination of groundwater in the Republic of Lithuania. Norges Geologiske Unders $\varnothing$ kelse Bulletin 424, 75-85. 
Laiconas, E. 1979. World of caves. Mokslas ir gyvenimas (Science and life). No 12. 9-12. [in Lithuanian].

Marcinkevičius, V. and Bucevičiute, S. 1986.Geological and hydrogeological conditions of sulphate karst development in North Lithuania. Lithuanian higher school scientific papers. Geologija. Vol. 7, 104-119. [in Russian].

Paukštys, B. 1996. Hydrogeology and groundwater protection problems in karst region of Lithuania. Geological Society of Lithuania, papers, 6, 1-72, Vilnius,

Pfeiffer, D. and Hahn, J. 1972. Karst of Germany. 187-223 in Herak, M. and Stringfield, V.T. (Editors) Karst: Important Karst Regions of the Northern Hemisphere. Elsevier, Amsterdam. 551p.

Pulido-Bosch, A. and Calaforra, J.M. 1993. The gypsum karstic aquifer of Sorbas (Almeria). 225-241 in Pulido-Bosch (Editor) Some Spanish Karstic Aquifers, University of Granada.

Sorochan, E.A., Troitzky, G.M., Tolmachov, V.V., Khomenko, V.P., Kkepokov, S.N., Metelyuk, N.S. and Grigoruk, P.D. 1985. Antikarst protection for buildings and structures. 2457-2460 in Proceedings of the Eleventh International Conference on Soil Mechanics and Foundation Engineering, San Francisco, 12-16 August 1985. Balkema, Rotterdam/Boston.

Ströbel, W. 1973. Der Grundgips im Raum Stuttgart als Model für Gipsauslaugung und Bildung von Erdfällen. T1-G 1-8 in Proceedings of a symposium on sinkholes and subsidence, Hannover, Deutsche Gessellschaft für Erd- und Grundbau. Essen.

Thomson, A., Hine, P.D., Greig, J.R. and Peach, D.W. 1996. Assessment of subsidence arising from gypsum dissolution: Technical Report for the Department of the Environment. Symonds Group Ltd, East Grinstead. 288pp.

Toulemont, M. 1984. Le karst gypseux du Lutétien supérieur de la région parisienne. Charactéristiques et impact sur le milieu urbain. Revue de Géologie Dynamique et de Géographie Physique. Vol. 25, 213-228. 